\title{
Effect of Different Levels of Nanoparticles Chromium Picolinate Supplementation on Performance, Egg Quality, Mineral Retention, and Tissues Minerals Accumulation in Layer Chickens
}

\author{
Nattapon Sirirat ${ }^{1}$, Jin-Jenn Lu ${ }^{1}$, Alex Tsubg-Yu Hung ${ }^{1} \&$ Tu-Fa Lien ${ }^{1}$ \\ ${ }^{1}$ National Chiayi University, Department of Animal Science, Chiayi, Taiwan \\ Correspondence: Tu-Fa Lien, National Chiayi University, Department of Animal Science, Chiayi, Taiwan. E-mail: \\ tflien@mail.ncyu.edu.tw
}

Received: November 6, 2012

Accepted: November 21, 2012 Online Published: January 15, 2013

doi:10.5539/jas.v5n2p150

URL: http://dx.doi.org/10.5539/jas.v5n2p150

\begin{abstract}
This study was conducted to investigate the effects of various levels of nanoparticles chromium picolinate on performance, egg quality, minerals retention, and tissues accumulation of layer chickens. This study used 54 seventy-week old post-molt laying hens randomly allocated into 0 (control), $500 \mathrm{ppb}\left(\mu \mathrm{g} \mathrm{kg}^{-1}\right) \mathrm{Cr}$ and $3000 \mathrm{ppb}$ $\mathrm{Cr}$ groups for a 60 -day experiment. The chromium was nanosize $(80.8 \pm 2.7 \mathrm{~nm})$ chromium picolinate (NanoCrPic) and each treatment was undertaken with six replicates. In the meantime, a total of 18 birds (1 bird/replicate) were used for metabolic experimentation. The results of the experiment indicated that there were no significant effects on body weight, feed intake, feed efficiency, and egg production of layers. Supplemental NanoCrPic could significantly $(\mathrm{p}<0.05)$ improve egg quality, or retention of chromium and zinc, but decrease shell ratio in the $60^{\text {th }}$ day eggs. The addition of NanoCrPic resulted in increased minerals accumulation in tissues such as $\mathrm{Cr}, \mathrm{Ca}$, and $\mathrm{P}$ concentration in the liver, $\mathrm{Cr}$ concentration in the yolk and $\mathrm{Ca}$ concentration in the eggshell. In conclusion, supplemental NanoCrPic improved $\mathrm{Cr}$ and $\mathrm{Ca}$ accumulation in the liver and egg, improved $\mathrm{Zn}$ and Mn retention in layer chickens.
\end{abstract}

Keywords: nanoparticles, chromium picolinate, mineral retention, laying hens

\section{Introduction}

Chromium is an essential mineral element in humans and domestic animals (Lukaski, 1999). Trivalent chromium (Cr (III)) is associated with the metabolism of carbohydrates, lipids and proteins in animals, it is also term as "glucose tolerance factor (GTF)", which regulates the metabolic action of insulin (Schwarz \& Mertz, 1957; Chen et al., 2009). Wang and Xu (2004) suggested that the absorption and utilization of $\mathrm{Cr}$ may be dependent on its status in the intestinal tract. However, different $\mathrm{Cr}$ (III) forms have diverse rates of absorption. Organic $\mathrm{Cr}$ (III) has greater biological availability than inorganic $\mathrm{Cr}$ (III) (NRC, 1997; Lukaski, 1999). Inorganic $\mathrm{Cr}$ (e.g. $\mathrm{CrCl}_{3}$ ) is in the range of 0.5-2\% (Mertz, 1969); while organic Cr (e.g. CrPic) is in the range of 10-25\% (Seerley, 1993).

In poultry, supplemental dietary CrPic increases production at low temperatures and increased CrPic results in an increase in egg production as well as resulting in an improved feed conversion ratio (Sahin et al., 2001; Yildiz et al., 2004). Moreover, organic $\mathrm{Cr}$ supplementation, particularly at $1200 \mathrm{ppb}$, increased the performance criteria, egg quality and serum insulin concentrations in Japanese quails (Sahin et al., 2002).

The nanoparticle, which is at least one dimension reduced to a nanometric size, exhibits new electrical, magnetic, mechanical, and biological properties (Gref et al., 1994), which have been determined as critical factors influencing particle uptake (Delie, 1998). Therefore, the new phenomena and properties of nanoparticles may have unique potential applications. In previous work, chromium nanoparticles were shown to produce beneficial effects on growth performance, body composition, resulting in increases in tissues $\mathrm{Cr}$ concentration in selected muscles. Additionally, they have been shown to enhance $\mathrm{Cr}$ digestibility and absorption in rats when supplemented with $200 \mathrm{ppb}$ NanoCr as well as altering certain blood metabolite concentrations (Zha et al., 2007a; Lien et al., 2009). Wang and Xu (2004) found that supplemented $200 \mu \mathrm{g} \mathrm{kg}^{-1}$ chromium nanoparticles (NanoCr) produce beneficial effects on carcass characteristics, pork quality and individual skeletal muscle weight, with approximately two- to three-fold higher tissue chromium deposition in selected muscle and organs compared to 
the control group, which implicated higher absorption and bioavailability of nanosize chromium. However, there are no existing studies about nano-sized chromium supplementation in poultry.

It is well known that mineral intake at high levels will have antagonist effects on other minerals. However, knowledge about this antagonist in $\mathrm{Cr}$ still is in its early stage. Some reports have indicated that iron-binding proteins are involved in chromium binding, transport, and storage (Feng et al., 2003). $\mathrm{CaCO}_{3}$ reduces $\mathrm{Cr}$ uptake and retention in rats (Seaborn \& Stoecker, 1990). It has also been reported that in stressed mice, loss of zinc, copper, iron, and manganese was reduced by supplemental chromium (Schrauzer et al., 1986; N. Sahin \& K. Sahin, 2002). Sahin and Sahin (2002) reported that the utilization of nitrogen and $\mathrm{Ca}, \mathrm{P}, \mathrm{Zn}$, and Fe, is improved by supplemental chromium and ascorbic acid.

Our hypothesis is that the nanoparticles chromium may also have an antagonistic effect on other minerals utilization and excretion, and consequently influence the animal performance. Therefore, this study was designed to compare the effects of dietary nanoparticles of chromium picolinate supplementation on the production performance, egg quality, minerals retention, and tissue minerals accumulation in layer chickens.

\section{Materials and Methods}

\subsection{Nanoparticle of Chromium Picolinate Determination}

The NanoCrPic was supplied by the Industrial Technology Research Institute of Taiwan (Shintsu, Taiwan). The NanoCrPic was measured by transmission electric microscopy (TEM). The average particle size of NanoCrPic was $80.8 \pm 2.7 \mathrm{~nm}$ (Figure 1).

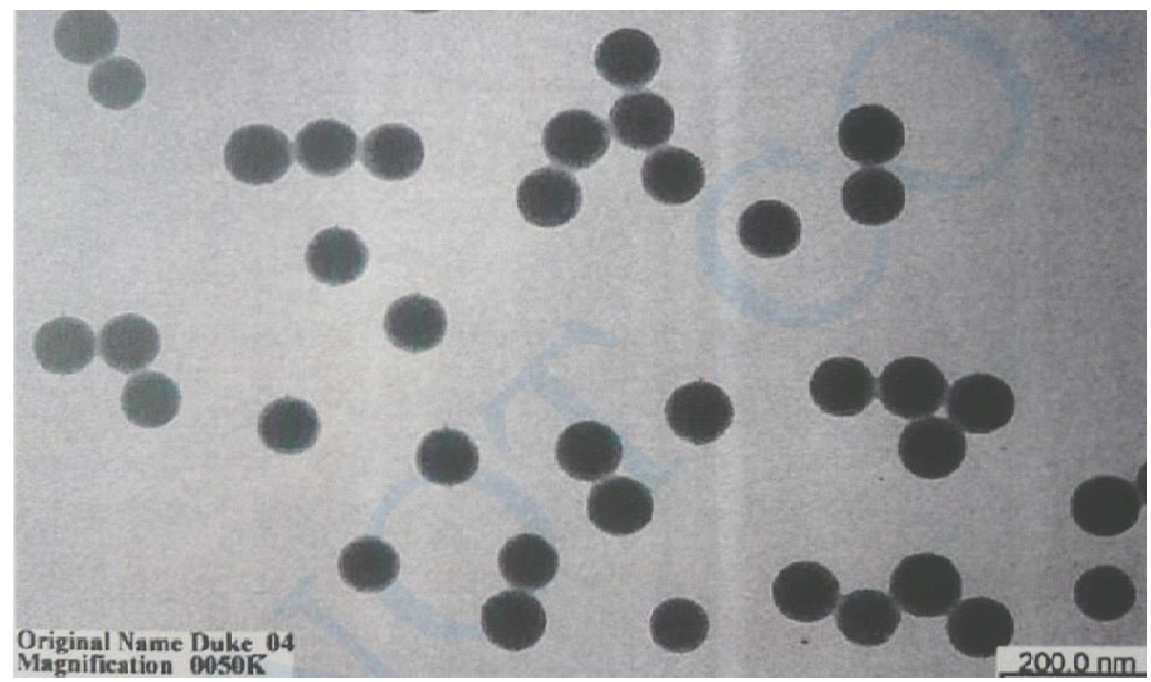

Figure 1. The image of nanoCr particles measured by TEM. Average particle size was $80.8 \pm 2.7 \mathrm{~nm}$

\subsection{Experimental Design}

A total of fifty-four 70-week old post molt laying hens (hy-line) were randomly selected for three dietary treatments with six replicates (three birds per replicate), with one hen per cage, (a cage length and width of 35 $\mathrm{cm} \times 20 \mathrm{~cm}$, respectively) in a completely randomized design. The three treatments used in the present study consisted of the following: (1) basal diet was formulated based on NRC (1994)(Table 1); (2) basal diet with 500 $\mathrm{ppb}\left(\mu \mathrm{g} \mathrm{kg}^{-1}\right) \mathrm{Cr}$ as nanoparticles CrPic (NanoCrPic) and (3) basal diet with $3000 \mathrm{ppb} \mathrm{Cr}$ as NanoCrPic for a 60 day experiment. Feed and water were ad libitum with floor feeding. The average room temperature at day time was $30.2 \pm 2.5^{\circ} \mathrm{C}$, lighting was about 15 hours. Egg production was recorded every day. 2 eggs from each bird was collected at middle ( $30^{\text {th }}$ day) and final $\left(60^{\text {th }}\right.$ day) period of the experiment for egg quality analysis, and the eggs at final period were also used for egg yolk and shell mineral content analysis. At the final of the experiment, 6 layers in each group ( 1 bird/replicate) were sacrificed and liver samples were taken for mineral analysis. The animals were reared according to the Guide for the Care and Use of Agricultural Animals in Agricultural Research and Teaching, and this study was approved by the University's Animal Care and Use Committee. 
Table 1. The basal diets of laying hen

\begin{tabular}{lc}
\hline Ingredients & $\mathrm{kg}$ \\
\hline Yellow Corn & 511 \\
Soybean meal & 250 \\
Full fat soybean meal & 100 \\
Soybean oil & 20 \\
Salt & 4 \\
Chloline chloride (50\%) & 1 \\
Limestone (35\%) & 100 \\
Dicalcium phosphate (18\%) & 11 \\
Vitamin premix & 1 \\
Mineral premix & \\
Total & 1 \\
Calculated value & 1000 \\
Crude protein (\%) & 19 \\
ME, kcal/kg & 2900 \\
Calcium (\%) & 3.86 \\
Available phosphorus (\%) & 0.25 \\
Copper (mg) & 6 \\
Zinc (mg) & 44 \\
Analyzed value & \\
Gross energy (\%) & 3860 \\
Crude protein (\%) & 21.57 \\
Chromium (ppb) & 961 \\
\hline
\end{tabular}

${ }^{1}$ Vitamin premix (content per kg): vitamin A 1,250,000 IU; vitamin $\mathrm{D}_{3}$ 25,000 ICU; vitamin E 2,000 IU; vitamin $\mathrm{K}_{3} 250 \mathrm{mg}$; vitamin $\mathrm{B}_{1} 200 \mathrm{mg}$; vitamin $\mathrm{B}_{6} 300 \mathrm{mg}$; vitamin $\mathrm{B}_{12} 12 \mathrm{mg}$; pantothenate $120 \mathrm{mg}$; niacin 350 $\mathrm{mg}$; biotin $200 \mu \mathrm{g}$; folic acid $100 \mathrm{mg}$.

${ }^{2}$ Mineral premix (content per kg): $\mathrm{Fe}\left(\mathrm{Fe}_{2}\left(\mathrm{SO}_{4}\right)_{3}\right) 0.2005 \mathrm{~g} ; \mathrm{Mn}\left(\mathrm{MnSO}_{4}\right) 0.076 \mathrm{~g} ; \mathrm{Cu}\left(\mathrm{CuSO}_{4}\right) 0.024 \mathrm{~g} ; \mathrm{Zn}(\mathrm{ZnO})$ $0.055 \mathrm{~g}$; I (KI) $0.0057 \mathrm{mg}$; $\mathrm{Se}\left(\mathrm{Na}_{2} \mathrm{SeO}_{3}\right) 0.0175 \mathrm{mg}$.

\subsection{Metabolic Trial}

Eighteen chickens $\left(1\right.$ bird replicate $\left.{ }^{-1}\right)$ were selected in last week of the experiment for the metabolic trial and conducted in duplicates, using the individual cages $(35 \mathrm{~cm} \times 20 \mathrm{~cm})$ and a plastic bag for collection of total excreta. The metabolic trial lasted five days. During the metabolic trial, the total amount of feed consumed (about $110 \mathrm{~g} \mathrm{day}^{-1}$ bird $^{-1}$ ) and total excreta voided (dry matter basis) from each chicken was recorded and sampled for components analysis. Minerals retention ratio was calculated using the following equation:

$$
\text { Mineral retention ratio }(\%)=\frac{(\mathrm{WFI} \times \mathrm{EF})-(\mathrm{WEV} \times \mathrm{EE})}{(\mathrm{WFI} \times \mathrm{EF})} \times 100
$$

WFI $=$ weight of feed intake $(110 \mathrm{~g})$

$\mathrm{EF}=$ concentration of element in feed

$\mathrm{WEV}=$ weight of total excreta voided

$\mathrm{EE}=$ concentration of element in total excreta

\subsection{Chromium Analysis}

Chromium analysis was base on the method of Anderson et al. (1985). Weighting $0.2 \mathrm{~g}$ of ground feed and feces, egg shell, yolk, and liver samples in duplicates were placed into a crystal beaker, in which $10 \mathrm{~mL}$ of $70 \%$ nitric acid was added and rested for $8 \mathrm{~h}$ before starting heat digestion at $80^{\circ} \mathrm{C}$ for $8 \mathrm{~h}$, left for cooling and after that the samples were diluted with $50 \mathrm{~mL}$ of deionized water. The filtered solution was kept in a polypolene bottle. Then, a polarized Zeeman atomic absorption spectrometer (Hitachi, Japan) equipped with a graphite furnace atomization was used for analysis. 


\subsection{Copper, Zinc, Manganese, and Iron Analysis}

According to AOAC (2000) methodology (NO. 2.109), the steps are as follows: weighting $1 \mathrm{~g}$ of feed, feces, liver, egg shell and yolk samples in duplicates crushed under the crucible. Following this, samples were subjected to $550^{\circ} \mathrm{C}$ for $5 \mathrm{~h}$ in a furnace to be converted to ash. The crucible was subjected to $10 \mathrm{~mL} 3 \mathrm{~N} \mathrm{HCl}$ under a heating plate and heated until the solution became clear. It was then allowed to cool (added to $50 \mathrm{~mL}$ with $0.1 \mathrm{~N} \mathrm{HCl}$ ). An atomic absorption spectrometer (Perkin Elmer, Atomic Analyst 100, USA) was used for copper, zinc, manganese and iron contents analysis.

\subsection{Calcium and Phosphorous Analysis}

According to AOAC (2000) methodology (Ca: No. 7.096, P: No. 7.119) the steps are as follows: weighting $1 \mathrm{~g}$ of feed, feces, and liver samples in duplicates crushed under the crucible. Following this, samples were subjected to $550^{\circ} \mathrm{C}$ for $5 \mathrm{~h}$ in a furnace to be converted to ash. The crucible was subjected to $10 \mathrm{~mL} 3 \mathrm{~N} \mathrm{HCl} \mathrm{under} \mathrm{a}$ heating plate and heated until the solution became clear. It was then allowed to cool (added to $50 \mathrm{~mL}$ with $0.1 \mathrm{~N}$ $\mathrm{HCl})$.

The calcium content analysis used a sample solution of $6 \mathrm{~mL}$ with added lanthanum $185.4 \mu \mathrm{L} 50000 \mathrm{mg} \mathrm{kg}^{-1}$. Then, analysis was performed using an atomic absorption spectrometer (Perkin Elmer, Atomic Analyst 100, USA).

For phosphorous determination, a sample of $1 \mathrm{~mL}$ plus $1 \mathrm{~mL}$ Vanadium-molybenum acid and $3 \mathrm{~mL}$ de-ionized water (a total of $5 \mathrm{~mL}$ ) were combined and left standing for $10 \mathrm{~min}$. An automatic scanning sub-ray spectrophotometer was then used for analysis (Beckman, DRR 640i, USA), with the wavelength set at $400 \mathrm{~nm}$.

\subsection{Determination Traits of Egg}

Egg albumen weight, yolk weight, and egg shell weight of each egg was measured (Fujihira Kogyo Inc., Tokyo). Egg shell thickness in the equator, blunt end, and pointed end of the eggs (excluding the shell membrane) was examined with a micrometer.

Egg shell strength was mechanically measured (Fujihira Kogyo Inc., Tokyo) to record the pressure used to rupture the shell.

Egg freshness was examined as follows: (1) egg weight was recorded; (2) eggs were broken and the heights of albumen and yolk, (short and long diameters of the albumen and the diameter of the yolks) were measured with a digital caliper; (3) yolk was separated from albumen and recorded; (4) the ratios of egg weight and thickness as well as albumen height were calculated; (5) the Haugh unit (HU) was examined (Nesheim et al., 1979):

Haugh unit $(\mathrm{HU})=100 \times \log \left(\mathrm{H}-1.7 \times \mathrm{W}^{0.37}+7.57\right)$

$\mathrm{H}=$ albumen height $(\mathrm{mm})$.

$\mathrm{W}=$ egg weight $(\mathrm{g})$.

\subsection{Statistical Analysis}

The experiment data were subjected to statistical analysis using SAS software (version 9.1, SAS 1998). The general linear model procedure (GLM procedure) was used based on the completely randomized design (CRD) model. Tukey's tests (SAS, 1998) were adopted in the model to determine the significant difference, according to the following model, treatment $(\mathrm{T})$ was the main effect.

$$
Y=\mu+T_{i}+P_{j}+e_{i j k}
$$

Where $\mathrm{Y}$ is the dependent variable, $\mu$ represents the mean, $\mathrm{P}$ is the pen (replicate, the experiment unit) effect and e is the random residual error term. The level of significantly different was set at $P<0.05$.

\section{Results and Discussion}

\subsection{The Effects of Various Levels of NanoCrPic on the Performance of Laying Hens}

The effect of dietary NanoCrPic supplementat on laying hens' performance parameters are shown in Table 2. During the experiment intervals at 30 and 60 days, the body weight, feed intake, and egg production were similar $(\mathrm{p}>0.05)$ among treatments. Supplemental NanoCrPic $500 \mathrm{ppb}$ either for 0-30 or 30-60 days increased egg weight $(\mathrm{p}=0.09)$ compared with NanoCrPic $3000 \mathrm{ppb}$ diet. 
Table 2. The effect of different level of nano-chromium on performance of laying hen

\begin{tabular}{|c|c|c|c|c|c|}
\hline \multirow{2}{*}{ Items } & \multicolumn{3}{|c|}{ Supplemented dietary NanoCrPic (ppb) } & \multirow{2}{*}{ SEM } & \multirow{2}{*}{$\mathrm{P}$ value } \\
\hline & 0 & 500 & 3000 & & \\
\hline & \multicolumn{5}{|c|}{$0-30$ days } \\
\hline Body weight $(\mathrm{g})$ & 1452 & 1479 & 1458 & 38.8 & 0.87 \\
\hline Feed intake $\left(\mathrm{g} \mathrm{bird}^{-1}\right.$ day $\left.^{-1}\right)$ & 107.8 & 105.6 & 105.5 & 1.02 & 0.28 \\
\hline Egg weight $(g)$ & $69.73^{\mathrm{ab}}$ & $71.27^{\mathrm{a}}$ & $67.24^{\mathrm{b}}$ & 0.60 & 0.09 \\
\hline Egg production $(\%)$ & 80.62 & 84.89 & 84.47 & 1.70 & 0.22 \\
\hline \multirow[t]{2}{*}{ Feed intake Egg mass ${ }^{-1}$} & $1.83^{\mathrm{ab}}$ & $1.75^{\mathrm{b}}$ & $1.95^{\mathrm{a}}$ & 0.05 & 0.06 \\
\hline & \multicolumn{5}{|c|}{ 30-60 days } \\
\hline Body weight (g) & 1460 & 1482 & 1498 & 10.7 & 0.11 \\
\hline Feed intake $\left(\mathrm{g} \mathrm{bird}^{-1}\right.$ day $\left.^{-1}\right)$ & 107.1 & 108.4 & 107.2 & 4.76 & 0.97 \\
\hline Egg weight $(g)$ & $67.45^{\mathrm{ab}}$ & $69.83^{\mathrm{a}}$ & $65.32^{\mathrm{b}}$ & 1.10 & 0.07 \\
\hline Egg production (\%) & 82.40 & 84.53 & 83.43 & 1.26 & 0.52 \\
\hline Feed intake Egg mass ${ }^{-1}$ & 1.90 & 1.84 & 1.98 & 0.06 & 0.32 \\
\hline
\end{tabular}

${ }^{\mathrm{a}, \mathrm{b}}$ Means within the same row without the same superscripts differ significantly $(\mathrm{p}<0.05)$.

SEM: standard error of mean.

$\mathrm{n}=7$.

In the egg quality parameters (Table 3 ) at the 30 day interval, no significant differences $(p>0.05)$ in egg strength, egg shell thickness, yolk weight, albumen ratio, yolk ratio, egg shell ratio, and yolk index were detected among groups. However, albumen index and Haugh unit of NanoCrPic groups were significantly better compared to the control group $(\mathrm{p}<0.05)$.

At the 60 day interval, the egg strength, egg shell thickness, albumen weight, and albumen ratio of laying hens did not differ significantly $(\mathrm{p}>0.05)$ between the treatment groups. The Haugh unit, albumen index and yolk index of layers was significantly greater $(p<0.05)$ in NanoCrPic supplemented groups as compared to the control group. However, the yolk weight, yolk ratio, and egg shell ratio were lower $(p<0.05)$ in supplemental NanoCrPic groups.

Table 3. The effect of different level of nano-chromium on egg quality of laying hens

\begin{tabular}{|c|c|c|c|c|c|}
\hline \multirow{2}{*}{ Parameter } & \multicolumn{3}{|c|}{ Supplemented dietary NanoCrPic (ppb) } & \multirow{2}{*}{ SEM } & \multirow{2}{*}{$P$ value } \\
\hline & 0 & 500 & 3000 & & \\
\hline & 30 days & & & & \\
\hline Egg strength $\left(\mathrm{kg} \mathrm{cm}^{-L}\right)$ & 3.37 & 3.43 & 3.19 & 0.23 & 0.76 \\
\hline Egg shell thickness (mm) & 0.36 & 0.38 & 0.37 & 0.02 & 0.94 \\
\hline Yolk weight $(\mathrm{g})$ & 19.9 & 19.1 & 18.5 & 0.46 & 0.18 \\
\hline Albumen weight (g) & $43.3^{\mathrm{ab}}$ & $44.3^{\mathrm{a}}$ & $41.6^{\mathrm{D}}$ & 0.55 & 0.03 \\
\hline Albumen ratio $(\%)$ & 62.0 & 61.9 & 61.8 & 0.73 & 0.98 \\
\hline Yolk ratio $(\%)$ & 28.5 & 26.8 & 27.5 & 0.55 & 0.17 \\
\hline Egg shell ratio (\%) & 9.39 & 9.69 & 9.67 & 0.52 & 0.90 \\
\hline Haugh unit (HU) & $63.9^{\mathrm{D}}$ & $83.4^{\mathrm{a}}$ & $84.8^{\mathrm{a}}$ & 1.97 & 0.0005 \\
\hline Albumen index (\%) & $4.54^{\mathrm{D}}$ & $8.07^{\mathrm{a}}$ & $8.15^{\mathrm{a}}$ & 0.29 & 0.0002 \\
\hline \multirow[t]{2}{*}{ Yolk index $(\%)$} & 38.6 & 42.1 & 49.1 & 7.33 & 0.61 \\
\hline & 60 days & & & & \\
\hline Egg strength $\left(\mathrm{kg} \mathrm{cm}^{-2}\right)$ & 3.23 & 2.78 & 3.14 & 0.30 & 0.57 \\
\hline Egg shell thickness (mm) & 0.29 & 0.33 & 0.33 & 0.02 & 0.24 \\
\hline Yolk weight $(\mathrm{g})$ & $19.7^{\mathrm{a}}$ & $17.9^{\mathrm{D}}$ & $17.7^{\mathrm{v}}$ & 0.40 & 0.02 \\
\hline Albumen weight (g) & 40.4 & 42.3 & 40.1 & 0.93 & 0.28 \\
\hline Albumen ratio $(\%)$ & 59.7 & 60.4 & 58.1 & 0.87 & 0.23 \\
\hline Yolk ratio $(\%)$ & $29.4^{\mathrm{a}}$ & $25.8^{\mathrm{c}}$ & $27.2^{\mathrm{D}}$ & 0.42 & 0.002 \\
\hline Egg shell ratio (\%) & $10.4^{\mathrm{a}}$ & $8.2^{\mathrm{b}}$ & $8.7^{\mathrm{D}}$ & 0.51 & 0.044 \\
\hline Haugh unit (HU) & $69.9^{\mathrm{b}}$ & $83.2^{\mathrm{a}}$ & $79.9^{\mathrm{a}}$ & 2.07 & 0.009 \\
\hline Albumen index (\%) & $3.33^{\mathrm{D}}$ & $7.97^{\mathrm{a}}$ & $7.25^{\mathrm{a}}$ & 0.54 & 0.001 \\
\hline Yolk index $(\%)$ & $35.5^{\mathrm{D}}$ & $42.1^{\mathrm{a}}$ & $41.8^{\mathrm{a}}$ & 0.84 & 0.002 \\
\hline
\end{tabular}

${ }^{\mathrm{a}, \mathrm{b}}$ Means within the same row without the same superscripts differ significantly $(\mathrm{p}<0.05)$.

SEM: standard error of mean. $n=7$. 
There is no report using nanosize chromium in laying hens. However, Sahin et al. $(2002 a ; 2003)$ stated that higher doses of supplemental chromium increased egg production, improved feed efficiency, increased egg weight, egg specific gravity, egg shell thickness, and Haugh unit in laying hens kept in low temperatures. Moreover, Kim et al. (1997) reported that feeding $800 \mathrm{ppb}$ CrPic to hens resulted in higher egg production, egg weight and egg mass. However, a later study reported that the same amount of organic or inorganic chromium did not influence the hen production performances (Lin \& Lin, 1999) and, in another experiment, organic or inorganic chromium fed at five weeks did not affect feed intake, egg production, egg and yolk weight, and Haugh unit (Piva et al., 2003). Lien et al. (1996) also indicated that the shell thickness was not affected by chromium picolinate supplementation (400 and $800 \mathrm{ppb}$ ) under thermally neutral conditions.

\subsection{The Effects of Various Levels of NanoCrpic on the Minerals Retention in Laying Hens}

Chromium retention and other minerals, namely $\mathrm{Cu}, \mathrm{Zn}, \mathrm{Fe}, \mathrm{Mn}, \mathrm{Ca}$, and $\mathrm{P}$ in layers are presented in Table $4 . \mathrm{Cr}$ retention in the $500 \mathrm{ppb}$ and $3000 \mathrm{ppb}$ NanoCrPic groups were significantly higher $(\mathrm{p}<0.0001)$ than the control group. When compared the control group, increased retention of $\mathrm{Zn}(\mathrm{p}=0.0002)$ was observed in the $500 \mathrm{ppb}$ and $3000 \mathrm{ppb}$ NanoCrPic groups and $\mathrm{Mn}$ in the $3000 \mathrm{ppb}$ group. However, retention of $\mathrm{Cu}, \mathrm{Fe}, \mathrm{Ca}$, and $\mathrm{P}$ show no difference when the chickens were fed with diets containing $500 \mathrm{ppb}$ and $3000 \mathrm{ppb}$ NanoCrPic.

Table 4. The effect of different level of nano-chromium on minerals retention ratio of laying hens

\begin{tabular}{lccccc}
\hline \multirow{2}{*}{ Items (\%) } & \multicolumn{2}{c}{ Supplemented dietary NanoCrPic $(\mathrm{ppb})$} & \multirow{2}{*}{ SEM } & \multirow{2}{*}{ P value } \\
\cline { 2 - 4 } & 0 & 500 & 3000 & & \\
\hline $\mathrm{Cr}$ & $3.58^{\mathrm{c}}$ & $16.67^{\mathrm{b}}$ & $21.21^{\mathrm{a}}$ & 2.57 & 0.0001 \\
$\mathrm{Cu}$ & 29.63 & 36.61 & 38.66 & 3.54 & 0.24 \\
$\mathrm{Zn}$ & $18.70^{\mathrm{c}}$ & $28.70^{\mathrm{a}}$ & $25.28^{\mathrm{b}}$ & 0.72 & 0.0002 \\
$\mathrm{Fe}$ & 26.04 & 33.54 & 29.18 & 2.09 & 0.11 \\
$\mathrm{Mn}$ & $39.81^{\mathrm{b}}$ & $41.30^{\mathrm{ab}}$ & $42.23^{\mathrm{a}}$ & 0.58 & 0.06 \\
$\mathrm{Ca}$ & 54.72 & 60.40 & 56.46 & 1.85 & 0.16 \\
$\mathrm{P}$ & 27.48 & 29.11 & 28.30 & 0.56 & 0.19 \\
\hline
\end{tabular}

$\overline{\mathrm{a}, \mathrm{b}, \mathrm{c}}$ Means within a row with no common superscripts are significantly different $(\mathrm{p}<0.05)$.

SEM: standard error of mean.

Retention ratio $=($ intake - excretion $) \div$ intake $\times 100 \%$

$\mathrm{n}=3$.

The administration of $\mathrm{Fe}$ inhibits the absorption of $\mathrm{Cr}$, indicating that $\mathrm{Cr}$ and $\mathrm{Fe}$ also share a common gastrointestinal transport mechanism, binding with transferring (Gomes et al., 2005). Antacid $\left(\mathrm{CaCO}_{3}\right)$ reduces $\mathrm{Cr}$ uptake and retention in rats (Seaborn \& Stoecker, 1990). Another research reported that the utilization of nitrogen and $\mathrm{Ca}, \mathrm{P}, \mathrm{Zn}, \mathrm{Fe}$ as well as $\mathrm{Cr}$, is improved by supplemental chromium and ascorbic acid (X. L. Sahin $\&$ F. P. Sahin, 2002). It has also been reported that in stressed mice, loss of zinc, copper, iron and manganese was reduced by supplemental chromium (X. L. Sahin \& F. P. Sahin, 2002; Schrauzer et al., 1986). Our results are in agreement with the results of Sahin and Sahin (2002), who reported that the retention of $\mathrm{Zn}$ was improved by supplemental $\mathrm{Cr}$ and ascorbic acid. In our previous study with broiler also indicated that supplemental NanoCrPic improved the retention of Zn (Sirirat et al., 2012), which may be owing to the Zn excretion being reduced in NanoCrPic group. Amatya et al. (2004) also reported that supplemental Cr had effect on the retention of $\mathrm{Zn}$ and $\mathrm{Mn}$ in broilers. However, retention of $\mathrm{Cu}, \mathrm{Fe}, \mathrm{Ca}$, and $\mathrm{P}$ were not different when the chickens were fed with diets containing $500 \mathrm{ppb}$ and $3000 \mathrm{ppb}$ NanoCrPic.

The experiment results confirm the theory that nanoparticle size could increase the ability of the molecules to pass through the intestinal mucosa for better absorption (Gilligan \& Po, 1991). Apart from particle size, surface charge and hydrophobicity can also affect the gastrointestinal uptake of nanoparticles (Po et al., 1995). Win and Feng (2005) also found that nanoparticles increased cellular uptake. Other studies have indicated that the transport of NanoCr exhibited considerably higher absorption efficiency than $\mathrm{CrPic}$ and $\mathrm{CrCl}_{3}$, respectively (Zha et al., 2007a). Lien et al. (2009) also reported the NanoCrPic enhances chromium digestibility and 
absorption in rats, as well as pigs (unpublished data). All of these reports agree with the results of the present study.

\subsection{The Effects of Various Levels of NanoCrpic on the Liver and Egg Minerals Accumulation in Laying Hens}

Liver minerals, namely $\mathrm{Cr}, \mathrm{Cu}, \mathrm{Zn}, \mathrm{Fe}, \mathrm{Mn}, \mathrm{Ca}$, and $\mathrm{P}$ in the layers are presented in Table $5 . \mathrm{Cr}, \mathrm{Ca}$, and $\mathrm{P}$ show significant increase $(\mathrm{p}<0.05)$ in the $500 \mathrm{ppb}$ and $3000 \mathrm{ppb}$ NanoCrPic groups. Other minerals such as $\mathrm{Cu}, \mathrm{Zn}$ and Fe were not affected by dietary NanoCrPic supplementation.

Table 5. The effect of different level of nano-chromium on liver minerals content of laying hens

\begin{tabular}{cccccc}
\hline \multirow{2}{*}{ Items } & \multicolumn{3}{c}{ Supplemented dietary NanoCrPic $(\mathrm{ppb})$} & & \\
\cline { 2 - 4 } & 0 & 500 & 3000 & & P value \\
\hline $\mathrm{Cr}\left(\mu \mathrm{g} \mathrm{kg}^{-1}\right)$ & $618^{\mathrm{b}}$ & $644^{\mathrm{b}}$ & $798^{\mathrm{a}}$ & 0.04 & 0.03 \\
$\mathrm{Cu}\left(\mathrm{mg} \mathrm{kg}^{-1}\right)$ & 6.71 & 7.56 & 7.13 & 0.68 & 0.68 \\
$\mathrm{Zn}\left(\mathrm{mg} \mathrm{kg}^{-1}\right)$ & 50.3 & 55.3 & 56.7 & 3.17 & 0.34 \\
$\mathrm{Fe}\left(\mathrm{mg} \mathrm{kg}^{-1}\right)$ & 109 & 105 & 101 & 6.84 & 0.70 \\
$\mathrm{Mn}\left(\mathrm{mg} \mathrm{kg}^{-1}\right)$ & 3.71 & 3.51 & 3.65 & 0.12 & 0.11 \\
$\mathrm{Ca}(\%)$ & $0.017^{\mathrm{b}}$ & $0.026^{\mathrm{a}}$ & $0.023^{\mathrm{a}}$ & 0.001 & 0.0003 \\
$\mathrm{P}(\%)$ & $0.169^{\mathrm{b}}$ & $0.189^{\mathrm{a}}$ & $0.184^{\mathrm{a}}$ & 0.004 & 0.01 \\
\hline
\end{tabular}

${ }^{\mathrm{a}, \mathrm{b}}$ Means within a row with no common superscripts are significantly different $(\mathrm{p}<0.05)$.

SEM: standard error of mean.

$\mathrm{n}=6$.

There were no differences in minerals namely $\mathrm{Cr}, \mathrm{Cu}, \mathrm{Zn}, \mathrm{Fe}, \mathrm{Mn}$, and $\mathrm{P}$ as regards to the yolks among the dietary treatments (Table 6). Ca in the yolk was significantly decreased in the $500 \mathrm{ppb}$ and $3000 \mathrm{ppb}$ NanoCrPic groups as compared to the control group $(\mathrm{p}=0.01)$.

Table 6. The effect of different level of nano-chromium on yolk minerals content of laying hens

\begin{tabular}{cccccc}
\hline \multirow{2}{*}{ Items } & \multicolumn{2}{c}{ Supplemented dietary NanoCrPic $(\mathrm{ppb})$} & \multirow{2}{*}{ SEM } & P value \\
\cline { 2 - 4 } & 0 & 500 & 3000 & & \\
\hline $\mathrm{Cr}\left(\mu \mathrm{g} \mathrm{kg}^{-1}\right)$ & 420 & 499 & 478 & 34.5 & 0.27 \\
$\mathrm{Cu}\left(\mathrm{mg} \mathrm{kg}^{-1}\right)$ & 25.0 & 20.5 & 20.7 & 1.74 & 0.15 \\
$\mathrm{Zn}\left(\mathrm{mg} \mathrm{kg}^{-1}\right)$ & 51.9 & 54.0 & 52.6 & 3.48 & 0.90 \\
$\mathrm{Fe}\left(\mathrm{mg} \mathrm{kg}^{-1}\right)$ & 89.9 & 100 & 108 & 6.58 & 0.16 \\
$\mathrm{Mn}\left(\mathrm{mg} \mathrm{kg}^{-1}\right)$ & 3.81 & 4.46 & 4.84 & 0.47 & 0.32 \\
$\mathrm{Ca} \mathrm{( \% )}$ & $0.17^{\mathrm{a}}$ & $0.16^{\mathrm{a}}$ & $0.14^{\mathrm{b}}$ & 0.005 & 0.01 \\
$\mathrm{P} \mathrm{( \% )}$ & 0.19 & 0.19 & 0.20 & 0.006 & 0.53 \\
\hline
\end{tabular}

${ }^{a, b}$ Means within a row with no common superscripts are significantly different $(\mathrm{p}<0.05)$.

SEM: standard error of mean.

$\mathrm{n}=6$.

The minerals of egg shell, i.e., $\mathrm{Zn}$ was significantly increased $(\mathrm{p}=0.0008)$ by NanoCrPic supplementation and also $\mathrm{Cr}$ in $3000 \mathrm{ppb}$ NanoCrPic groups $(\mathrm{p}=0.003)$; whereas $\mathrm{Cu}, \mathrm{Fe}, \mathrm{Mn}, \mathrm{Ca}$, and $\mathrm{P}$ showed no differences among the dietary treatments (Table 7). 
Table 7. The effect of different level of nano-chromium on egg shell minerals content of laying hens

\begin{tabular}{cccccc}
\hline \multirow{2}{*}{ Items } & \multicolumn{3}{c}{ Supplemented dietary NanoCrPic $(\mathrm{ppb})$} & \multirow{2}{*}{ SEM } & P value \\
\cline { 2 - 4 } & 0 & 500 & 3000 & & \\
\hline $\mathrm{Cr}\left(\mu \mathrm{g} \mathrm{kg}^{-1}\right)$ & $254^{\mathrm{b}}$ & $273^{\mathrm{b}}$ & $355^{\mathrm{a}}$ & 18.0 & 0.003 \\
$\mathrm{Cu}\left(\mathrm{mg} \mathrm{kg}^{-1}\right)$ & 8.18 & 8.62 & 7.76 & 0.71 & 0.70 \\
$\mathrm{Zn}\left(\mathrm{mg} \mathrm{kg}^{-1}\right)$ & $4.04^{\mathrm{b}}$ & $6.14^{\mathrm{a}}$ & $6.21^{\mathrm{a}}$ & 0.36 & 0.0008 \\
$\mathrm{Fe}\left(\mathrm{mg} \mathrm{kg}^{-1}\right)$ & 79.4 & 88.8 & 74.7 & 6.55 & 0.32 \\
$\mathrm{Mn}\left(\mathrm{mg} \mathrm{kg}^{-1}\right)$ & 2.44 & 2.23 & 3.20 & 0.32 & 0.11 \\
$\mathrm{Ca}(\%)$ & 37.5 & 38.5 & 40.4 & 1.42 & 0.35 \\
$\mathrm{P}(\%)$ & 0.78 & 0.94 & 0.96 & 0.11 & 0.47 \\
\hline
\end{tabular}

a,b,c Means within a row with no common superscripts are significantly different $(\mathrm{p}<0.05)$.

SEM: standard error of mean.

$\mathrm{n}=6$.

In mouse, Anderson et al. (1989) reported that supplemental chromium resulted in an accumulation of $\mathrm{Cr}$ in the liver. Zha et al. (2007c) reported that nanoparticles chromium supplementation shown effects on primary tissues such as kidney, liver and hind leg muscle in rats. In addition, $\mathrm{Cr}$ has been shown that supplemental chromium led to increased $\mathrm{Cr}$ and $\mathrm{Zn}$ in serum, liver, kidney and longissimus muscle of laying hens and Japanese quails (Sahin et al., 2002a; Sahin et al., 2002b), but Fe concentrations were not affected in Japanese quails. Our previous study also indicated that NanoCrPic supplementation in broilers diet increased the concentration of $\mathrm{Cr}$ and $\mathrm{Ca}$ in the liver (Sirirat et al., 2012). Those reports were agreed with our results. From the result of this study it indicated that chromium accumulated major in liver.

Chemical analysis has shown the presence of other minerals $(\mathrm{Cr}, \mathrm{Co}, \mathrm{Cu}, \mathrm{Mn}, \mathrm{Ni}$, and $\mathrm{Zn}$ ) in eggs (Dauwe et al., 2005). Butcher and Miles (2002) suggested that the dry eggshell is approximately $95 \%$ calcium carbonate, $0.3 \% \mathrm{P}$, $0.3 \% \mathrm{Mg}$, with traces of $\mathrm{Na}, \mathrm{K}, \mathrm{Zn}, \mathrm{Mn}$, and $\mathrm{Cu}$, which is consistent with our results.

The results pertaining to values of minerals in the yolk are in agreement with those of Mabe et al. (2003) and Piva et al. (2003) who reported that hen diets containing trace minerals, namely $\mathrm{Cr}, \mathrm{Zn}$, and $\mathrm{Cu}$; and $\mathrm{Cr}$ supplementation did not affect yolk mineral content. From the present study, it is indicated that chromium supplementation did not affect yolk and egg shell minerals composition except as regards to calcium in the yolk.

\section{Conclusion}

This study found that chickens fed with NanoCrPic showed improved $\mathrm{Cr}$ and $\mathrm{Ca}$ accumulation in the liver and egg; NanoCrPic supplementation was also shown to improve the $\mathrm{Zn}$ and Mn retention of laying chickens.

\section{References}

A.O.A.C. (2000). Official Methods of Analysis. 17th ed. Association of Official Analytical Chemist. Virginia, U.S.A.

Amatya, J. L., Haldart, S., \& Ghosh, T. K. (2004). Effects of chromium supplementation from inorganic and organic sources on nutrient utilization, mineral metabolism and meat quality in broiler chickens exposed to natural heat stress. Anim. Sci., 79, 241-253.

Anderson, R. A. (1987). Chromium: Trace Elements in Human and Animal nutrition (pp. 225-244). New York: Academic Press.

Anderson, R. A., \& Kozlovsky, A. S. (1985). Chromium intake, absorption and excretion of subjects consuming self-selected diets. Am. J. Clin. Nutr., 41, 1177-1183.

Butcher, G. D. \& Miles, R. (2002). Subject: Concepts of eggshell quality. Retrieved from http://edis.ifas.ufl.edu/VM013

Chen, W. Y., Chen, C. J., Liu, C. H., \& Mao, F. C. (2012). Chromium supplementation enhances insulin signalling in skeletal muscle of obese KK/HIJ diabetic mice. Diabetes Obese Metab., 11, 293-303. 
Dauwe, T., Janssens, E., Bervoets, L., Blust, R., \& Eens, M. (2005). Heavy metal concentrations in female laying great tits (Parus major) and their clutches. Arch. Envir.l Contam. Toxicol., 49, $249-256$. http://dx.doi.org/10.1007\%2Fs00244-003-0209-z

Delie, F. (1998). Evaluation of nano-and microparticle uptake by the gastrointestinal tract. Adv. Drug Del. Rev., 34, 221-233. http://dx.doi.org/10.1016\%2FS0169-409X\%2898\%2900041-6

Feng, W., Li, B., Liu, J., Chai, Z., Zhang, P., Gao, Y., \& Zhao, J. (2003). Study of chromium containing proteins in sub cellular fractions of rat liver by enriched stable isotopic tracer technique and gel filtration chromatography. Analyt. Bioanalyt. Chem., 375, 363-368.

Gilligan, C. A., \& Po, A. L. W. (1991). Factors affecting drug release from a pellet system coated with an aqueous colloidal dispersion. Intern. http://dx.doi.org/10.1016\%2F0378-5173\%2891\%2990100-3

Gomes, M. R., Rogero, M. M., \& Tirapegui, J. (2005). Considerations about chromium, insulin and physical exercise. Revista Brasil. de Med. do Esporte, 11, 246-250. http://dx.doi.org/10.1590\%2FS1517-86922005000500003

Gref, R., Minamitake, Y. M., Peracchia, T., Trubetskoy, V., Torchilin, V., \& Langer, R. (1994). Biodegradable long-circulating polymeric nanospheres. Science, 1600-1603. http://dx.doi.org/10.1126\%2Fscience.8128245

Kim, J. D., Han, I. K, Chae, B. J., Lee, J. H., Park, J. H., \& Yang, C. J. (1997). Effects of dietary chromium picolinate on performance, egg quality, serum traits and mortality rate of brown layers. Asian-Australa. J. Anim. Sci., 10, 1-7.

Lien T. F., Chen, S. Y., Shiau, S., Froman, D., \& Hu, C. Y. (1996). Chromium picolinate reduces laying hen serum and egg yolk cholesterol. Profess. Anim. Sci., 12, 77-80.

Lien, T. F., Yeh, H. S., Lu, .F. Y., \& Fu, M. (2009). Nanoparticles of chromium picolinate enhance chromium digestibility and absorption. J. Sci. Food Agri., 89, 1164-1167. http://dx.doi.org/10.1002\%2Fjsfa.3569

Lin, X. L., \& Lin, F. P. (1999). Effects of organic chromium on the production performance and yolk cholesterol of laying hens. J. Fujian Agricul. University, 28, 483-487.

Lukaski, H. C. (1999). Chromium as a supplement. Ann. Rev. Nutr., 19, 279-302. http://dx.doi.org/10.1146\%2Fannurev.nutr.19.1.279

Mabe, I., Rapp, C., Bain, M. M., \& Nys, Y. (2003). Supplementation of a corn-soybean meal diet with manganese, copper, and zinc from organic or inorganic sources improves eggshell quality in aged laying hens. Poult. Sci., 82, 1903-1913.

Mertz, W. (1969). Chromium occurrence and function in biological systems. Physiol. Rev., 49, 163-239.

National Research Council. (1994). Nutrient requirements of poultry, ninth revised edition. National Academy Press, Washington, D.C.

National Research Council. (1997). The Role of Chromium in Animal Nutrition. Washington, D.C: National Academy Press.

Nesheim, M. C., Austic, R. E., \& Card, I. E. (1979). Poultry Production. 12th ed. Lea and Febiger, Malvern, PA.

Piva, A., Meola, E., Gatta, P. P., Biagi, G., Castellani, G., Mordenti, A. L., ... Mordenti, A. (2003). The effect of dietary supplementation with trivalent chromium on production performance of laying hens and the chromium content in the yolk. Anim. Feed Sci. Technol., 106, 149-163. http://dx.doi.org/10.1016\%2FS0377-8401\%2803\%2900006-3

Po, A. L. W., Rogers, E., Shepphard, M., \& Scott, E. M. (1995). Delivery systems for non-parenteral vaccines. Adv. Drug Del. Rev., 18, 101-109.

Sahin, K., \& Sahin, N. (2002). Effects of chromium picolinate and ascorbic acid dietary supplementation on nitrogen and mineral excretion of laying hens reared in low ambient temperature $\left(7^{\circ} \mathrm{C}\right)$. Acta Veter. Brno., 71, 183-189. http://dx.doi.org/10.2754\%2Favb200271020183

Sahin, K., Kucuk, O., \& Sahin, N. (2001). Effects of dietary chromium picolinate supplementation on performance and plasma concentrations of insulin and corticosterone in laying hens under low ambient temperature. J. Anim. Physiol. A. Anim.. Nutr., $85, \quad$ 142-147. http://dx.doi.org/10.1046\%2Fj.1439-0396.2001.00314.x 
Sahin, K., Sahin, N., \& Kucuk, O. (2002a). Effects of dietary chromium picolinate supplementation on serum and tissue mineral contents of laying Japanese quails. J. Trace Elem. Experim. Med., 15, 163-169. http://dx.doi.org/10.1385\%2FBTER\%3A87\%3A1-3\%3A113

Sahin, K., Sahin, N., \& Kucuk, O. (2003). Effects of chromium, and ascorbic acid supplementation on growth, carcass traits, serum metabolites and antioxidant status of broiler chickens reared at a high ambient temperature. Nutr. Res., 23, 225-238. http://dx.doi.org/10.1016\%2FS0271-5317\%2802\%2900513-4

Sahin, N., Onderci, M., \& Sahin, K. (2002b). Effects of dietary chromium and zinc on egg production, egg quality, and some blood metabolites of laying hens reared under low ambient temperature. Biol. Trace Elem. Res., 15, 163-169. http://dx.doi.org/10.1385\%2FBTER\%3A85\%3A1\%3A47

Schrauzer, G. N., Shrestha, K. P., Molenaar, T. B., \& Mead, S. (1986). Effects of chromium supplementation on food energy utilization and the trace-element composition in the liver and heart of glucose-exposed young mice. Biol. Trace Elem. Res., (Abstr.). http://dx.doi.org/10.1007\%2FBF02916517

Schwarz, K., \& Mertz, W. (1957). A glucose tolerance factor and its differentiation from factor 3. Arch. Biochem. Biophy., 72, 515-518. http://dx.doi.org/10.1016\%2F0003-9861\%2857\%2990228-X

Seaborn, C. D., \& Stoecker, B. J. (1990). Effects of antacid or ascorbic acid on tissue accumulation and urinary $\begin{array}{llllll}\text { excretion of } & { }^{51} \text { chromium. } & \text { Nutr. } & \text { Res., } & 10, & 1401-1407 .\end{array}$ http://dx.doi.org/10.1016\%2FS0271-5317\%2805\%2980132-0

Seerley, R. W. (1993). Organic chromium and manganese in human nutrition: important possibilities for manipulating lean meat deposition in animals. Proceeding of Alltech's 9th Annual Symposium (pp. 41-51). Nicholasville, KY, USA.

Sirirat, N., Lu, J, J., Alex Hung, T. Y., Chen, S. Y. \& Lien, T. F. (2012). Effects Different Levels of Nanoparticles Chromium Picolinate Supplementation on Growth Performance, Mineral Retention, and Immune Responses in Broiler Chickens. J. Agric. Sci., 4, 48-58. http://dx.doi.org/10.5539/jas.v4n12p48

Statistical Analysis System Institute Inc. (1998). SAS/STAT User's guide: statistics, Version 6.06, Cary, NC, USA: SAS Institute Inc.

Wang, M. Q, Li, H., He, Y. D., Wang, C., Tao, W. J., \& Du, Y. J. (2012). Efficacy of dietary chromium (III) supplementation on tissue chromium deposition in finishing pigs. Biol. Trace Elem. Res., 148, 316-21. http://dx.doi.org/10.1007\%2Fs12011-012-9369-x

Wang, M. Q. \& Xu, Z. R. (2004). Effect of chromium nano-particle on growth performance, carcass characteristics, pork quality and tissue chromium in finishing pigs. Asian-Austral. J. Anim. Sci., 17, 1118-1122.

Win, K. Y., \& Feng, S. S. (2005). Effects of particle size and surface coating on cellular uptake of polymeric nanoparticles for oral delivery of anticancer drugs. Biomater., 26, 2713-2722.

Yildiz, A., Parlat, S., \& Yazgan, O. (2004). The effects of organic chromium supplementation on production traits and some serum parameters of laying hens. Revue de Méd. Vétér., 12, 642-646.

Yoshida, M., Hatakeyama, E., Hosomi, R., Kanda, S., Nishiyama, T., \& Fukunaga, K. (2010). Tissue accumulation and urinary excretion of chromium in rats fed diets containing graded levels of chromium chloride or chromium picolinate. J. Toxicol. Sci., 35, 485-491. http://dx.doi.org/10.2131\%2Fjts.35.485

Zha, L. Y., Wang, M. Q., Xu, Z. R., \& Gu, L. Y. (2007b). Efficacy of chromium(III) supplementation on growth, body composition, serum parameters, and tissue chromium in rats. Biol. Trace Elem. Res., 119, 42-50. http://dx.doi.org/10.1007\%2Fs12011-007-0042-8

Zha, L. Y., Xu, Z. R., Wang, M. Q., \& Gu, L. (2007a). Choromium nanoparticle exhibits higher absorption efficiency than chromium picolinate and chromium chloride in Caco-2 cell monalayers. J. Anim. Physiol. Anim. Nutr., (Berl)., 92, 131-140.

Zha, L. Y., Xu, Z. R., Wang, M. Q., \& Gu, L. Y. (2007c). Effects of chromium nanoparticles dosage on growth, body composition, serum hormones and tissue chromium in Sprague-Dawley rats. J. Zhejiang University Science B, 8, 323-330. 